Implementing the New Watershed Approach: Insights from the United States

\title{
Building Sustained Partnerships
}

Die neve Wasserrahmenrichtlinie spiegelt einen internationalen Trend zu neven Ansätzen des Ressourcenmanagements wider. Dabei kann unter anderem auf Erfahrungen aus den USA zurückgegriffen werden. Flusseinzugsgebietsbezogene Initiativen haben dort zu verstärkten Umweltschutzmaßnahmen, institutionellen Veränderungen und auch wirtschaftlichen Erfolgen geführt. Vor allem haben sie die Problemlösungskapazität und damit die tatsächlichen Umsetzungschancen gesteigert. Erfolgsfaktoren für erfolgreiche Managementansätze sind die Beteiligung auch von Regierungsorganisationen und entsprechende Personalkapazitäten, flexible Organisationsstrukturen zur Bewältigung der Transaktionskosten, eine solide Informations- und Planungsbasis sowie natürlich entsprechender Problemlösungsdruck.

$\mathrm{T}$ he new Water Framework Directive adopting river basins for water management in the European Union reflects the growing international trend toward the use of natural systems for coordination and integration of environmental resource management. While there is a long history of river basins as frameworks for managing water resources, in Europe, the United States, and elsewhere a ,new“ watershed approach has emerged that expands upon traditional efforts and accommodates greater collaboration, an expanded set of interests, and a broader set of ecological and functional goals. Systematic evaluation of the new approach has received modest scholarly attention, but a number of recent efforts have explored process, organization, and contextual dimensions of watershed initiatives and their relationships to accomplishments (1). This article draws heavily from our recent study (2) to outline a number of key dimensions and implementation challenges found in the US as a point of reference for EU resource managers faced with the task of implementing the new Water Framework Directive.

\section{Watershed Partnerships}

There are many conceptualizations of the new watershed approach. The new approach strives for improved interagency and intergovernmental coordination at the watershed level and improved linkages between various related but often separated governmental programs. Yet, the new approach goes farther, incorporating ,grass- roots partnerships" and decentralized decisionmaking as core themes. In fact, there is a wide spectrum of „bottom-up“ watershed activity and organization associated with these efforts, ranging from informal citizen-based action to the formation of non-governmental watershed associations or extensive citizen involvement and collaboration in agency watershed programs. The emerging watershed approach entails a collaborative partnership between government and an inclusive collection of watershed stakeholders - and a blending of ,top-down“ and ,,bottoms-up“ action and decision-making. Key elements that characterize the new watershed approach include:

- The use of watersheds and subwatersheds as the fundamental analytical and management unit,

- broader scope, ecosystem-oriented goals,

- science-based and information-driven assessments, plans and decisions,

- multi-agency and intergovernmental coordination, including information exchange, resource sharing, and shared decision-making,

- collaborative, voluntary and consensus-oriented interaction of local stakeholders, governmental units and agencies, communities and other watershed interests, and the formation of publicprivate partnerships,

- action-oriented and adaptive planning and management to reflect changing resource, socio-economic and institutional conditions, and new knowledge gained from ongoing monitoring and evaluation. Although individual watershed initiatives rarely fulfill every dimension of this somewhat idealized framework, it clearly characterizes the watershed approach as far more than simply unilateral actions by governmental agencies to solve problems at the watershed scale. Decentralized decisionmaking and non-governmental ,grassroots“ partnerships inherent in the new watershed approach enhance the prospects for crafting durable, locally acceptable solutions to problems and fostering community-based environmental stewardship. Interaction and collaboration among local stakeholders, organizations, and communities - working with higher level governments - to identify and solve ,their" problems are central attributes of the emerging paradigm. Thus the watershed is not only a geographic or hydrologic unit, but an institutional nexus as well (3).

\section{Successful Initiatives}

Watershed initiatives are able to capitalize on their arrangements with varying degrees of success, and indeed, given the complexities and long-term nature of measurable environmental change, evaluation criteria must encompass intermediate accomplishment measures. Numerous initiatives in the US have been generally successful at increasing adoption of management practices and pollution control technology that is expected to lead to measurable improvements in say, water quality or aquatic habitat. Many have also influenced various institutional changes, for example new formal project review protocols, or brought about economic gains associated with riverside development, recreation, fisheries, water supply, and wastewater treatment, among others. However, some of the most prevalent accomplishments are intangible impacts related to the process of coordination and interaction.

One of the less tangible but perhaps most important accomplishments of new watershed initiatives is their effect on problem-solving capacity. New watershed approaches expand the geographic, substantive and functional scope of the enterprise, thereby fostering multi-issue analysis and problemsolving and the potential for integrated environmental management. Watershed partnerships facilitate information sharing and interagency coordination, including the targeting and/or pooling of technical and financial resources - requisites for problem-solving that have often stymied traditional management approaches. A history of sustained interaction and cooperation, shared incremental successes, and institutional memory - characteristics common to more experienced watershed partnerships - lays the base for addressing com- 
plex distributional resource problems. Problemsolving capacity is also strengthened when the scientific and communication capacity of individual partners in a watershed initiative is enhanced. Finally, new watershed approaches can effectively involve local governments, influentials, and private interests in the initiative. This can have the effect not only of influencing watershed public opinion and understanding, which are important preconditions for action, but also of engaging those private and local governmental entities that have the authority to act in areas related to land use and development. The ability to positively affect problem-solving capacity, with an emphasis on increased ability to implement proposed solutions within the socio-economic, cultural and political context of a particular watershed, is one of the most significant features of new watershed approaches.

\section{- Five Key Dimensions}

The effectiveness and potential accomplishments of watershed initiatives may be influenced by many factors, including historical resource management relationships and related conflicts, funding, and underlying regulatory arrangements. While more comprehensive reviews are available elsewhere (4), we highlight a few key dimensions that have raised important implementation issues in the US.

\section{- Participation and Staffing}

By definition, these initiatives involve diverse participation reflective of a range of interests. It is clear that nongovernmental interests such as local citizens, community leaders, and interest groups, play a pivotal role in launching most watershed partnerships. This locally based initiative notwithstanding, local and state agencies and their staffs also play important and complementary roles in both starting and sustaining these efforts. Governmental agencies and staff provide critical sustenance for watershed partnerships in the form of funding, staff and organizational support, scientific information and analysis, shared leadership, supportive program management and recognition and legitimacy. There are two broad categories of staffing associated with watershed partnerships: staff involved with the organizational support and development activities required to sustain the partnership enterprise; and staff involved in the planning and execution of various programmatic activities. With regard to programmatic staffing, partnerships have drawn extensively on govern- ment agencies and universities for watershed technical analysis, ecological and related assessments, and much of the on-the-ground implementation activities. While interest groups are critical participants and contribute a variety of resources and perspectives, watershed partnerships in the US rely heavily on the active involvement of government, especially state environmental and local natural resource agencies, at all stages of their collaborative undertakings.

\section{- Organization}

Watershed initiatives come in varied forms; there is no single prescription or model. Yet, most examples exhibit a degree of organizational formality - in the form of articles of incorporation or charters, bylaws, structural arrangements, and nonprofit organizational status. These arrangements are essential for effective functioning and to meet accountability requirements associated with formal recognition and governmental financial support. However, watershed partnerships, particularly with regard to the nongovernmental and citizen dimensions, generally do not have the comparatively enduring and stable character of governmental agencies and units. They are dynamic and nonlinear; they ebb and flow, become dormant or extinct, and resurface with old and new participants under new names and organizational forms.

Furthermore, the balance of responsibility within the watershed partnership between governmental and nongovernmental participants can shift markedly during the evolution of the partnership and the execution of its programs. Watershed partnerships are characterized by numerous partner interactions sustained over long periods of time, and successful efforts unavoidably involve high transaction costs in comparison to traditional „top-down“ environmental management. While many forms appear to be effective, structural flexibility may be a critical element of the new approach.

\section{- Information}

Adequate scientific data and analytical capacity are essential for sound watershed planning and decision-making. While not always available initially, the more successful partnerships have been able to acquire or find ways to develop requisite information. In general, they have been able to access technical assistance from a variety of providers, including state, tribal and federal agencies and academic institutions. Watershed monitoring and applied research also provide information and guidance for experimental learning through pilot watershed management interventions and adaptive management.

\section{Planning}

Watershed plans appear to be necessary precedents for successful watershed management, protection, and restoration interventions. A watershed plan includes a sound diagnosis and understanding of the problems, shows forethought, presents alternative solutions, and identifies feasible actions. Effective plans might range in size and content from skeletalized documents of only a few pages to multi-volume comprehensive reports. Plans do not necessarily need to begin as a comprehensive assessment across a broad scope of issues; they can be „living documents“ that evolve over time to reflect the complexity of the issues being addressed.

There are other benefits to planning in addition to providing a rationalized set of actions. The process of developing a watershed plan can help partners to see the complex interconnections between natural systems and social and economic activities, for example, land use patterns and land management activities. Plans and planning processes can help resolve disputes by providing a mechanism for joint fact-finding and agreement on priority problems and actions. Practically, plans can enhance opportunities for funding by demonstrating multiple-interest-based priorities and connections between specific project actions and a larger, systems-oriented process.

\section{Issue Salience}

A final dimension that appears to be of critical importance in the initiation, sustenance, and success of watershed partnerships is the salience, immediacy, or priority of the problems/issues to be addressed. The issue(s) must have high salience in the eyes of prospective partners and, to some degree, in the eyes of the general public in order to provide the motivation for pursuing, undertaking, and sustaining a collaborative watershed effort. Issue salience and consequent motivation for collective action have emerged from:

- high values associated with a particular resource, - perceptions of threat to a highly valued resource, - severe resource degradation,

- a perceived threat of externally imposed action,

- potential economic gains, or

- significant incentives, such as funding, for joint action. 


\section{- Concluding Thoughts}

As recognized in the Water Directive Framework, implementing a basin management approach in the EU will involve extensive co-ordination and integration across multiple national and sub-national jurisdictions. Experience in the US suggests that watershed based initiatives can be effective institutional innovations for addressing the range of complexities associated with water and related resource management. Their flexibility and nonprescribed forms may be key to these accomplishments, and as in the US, the EU is likely to see major management innovations achieved by the interactions of agency and non-governmental actors across the variety of river basin landscapes.

\section{References}

(1) For example, Leach, W.D.: Evaluating Watershed Partnerships in California: Theoretical and Methodological Per- spectives. Dissertation, University of California, Davis 2000; Genskow, K.D.: Critical Factors for Watershed Partnerships: An Analysis of Actions and Accomplishments. Doctoral Dissertation, University of Wisconsin, Madison 2001.

(2) Born, S.M./ Genskow, K.D.: The Watershed Approach: An Empirical Assessment of Innovation in Environmental Management. In: National Academy of Public Administration: Environment.Gov: Transforming Environmental Protection for the 21st Century. Research Papers 7-10, Volume II, 2000. Internet: http://www.napawash.org/pc_economy_environment/recent_publications.html

(3) Born, S.M./ Genskow, K.D.: Exploring the Watershed Approach: Critical Dimensions of State-Local Partnerships. River Network 1999 (free download at www.rivernetwork.org). (4) Kenney, D.S./ McAllister, S.T./ Caile, W.H./ Peckham, J.S.: The New Watershed Source Book: A Directory and Review of Watershed Initiatives in the Western United States. Natural Resources Law Center, University of Colorado School of Law 2000; Margerum, R.D.: Integrated Environmental Management: The Foundations of Successful Practice. In: Environmental Management, Vol. 24 (1999),
Nr. 2, S. 151-166; Born, S. M./ Genskow, K. D.: Toward Understanding New Watershed Initiatives: A Report From the Madison Watershed Workshop. University of Wisconsin 2001. Available on the internet at www.tu.org/newsstand/library_pdfs/watershed.pdf

\section{Die Autoren}

Kenneth D. Genskow is lecturer at the University of Wisconsin - Cooperative Extension, Stephen M. Born is professor at the Department of Urban and Regional Planning and the Institute for Environmental Studies at the University of Wisconsin.

Contact: Kenneth Genskow, University of Wisconsin, Environmental Resources Center, Cooperative Extension, 102 Smith Hall, HIRAM, 1545 Observatory Drive, Madison, WI 53706, USA.

E-mail: kgenskow@facstaff.wisc.edu; smborn@facstaff.wisc.edu

\section{Do Water Parliaments and Fees Pay?}

\section{In Frankreich haben flussgebietsbezogene Managementansätze eine lange Tra- dition. Die Umsetzung der Wasserrahmenrichtlinie war daher unproblematisch. Das neve Wassergesetz stellt im Kern eine Weiterentwicklung bewährter Insti- tutionen und Instrumente dar. Von Bedeutung sind hier insbesondere die staat- lichen Flusseinzugsgebietsagenturen sowie die so genannten Wasserparla- mente, die die Stakeholder einbinden. Auf der Ebene der Instrumente wird das bereits eingeführte Instrument der Nutzungsgebühren noch erheblich ausgewei- tet. Während Partizipation und Selbstverwaltung sicher auf dem Habenkonto des französischen Beispiels verbucht werden können, bleibt fraglich, inwieweit dadurch tatsächlich Umweltverbesserungen erreicht werden.}

\footnotetext{
A

Von Jan C. Bongaerts fter the adoption in October 2000 and the publication in December 2000 of the European Union Water Framework Directive (EU WFD), member states have to start with the transposition and the actual implementation of international water policy and water resources management. For France, the EU WFD is familiar, because the principle of water resources management at the level of river basins, as contained in the Directive, has already been established by the Water Act of 1964 . Hence, it is not surprising to see that, just a little more than one year after the publication of the EU WFD, the
}

French Parliament adopted a proposal for a Water Act which is to replace the Water Act of 1964 (and the important amendments of 1992) in the night of 10 January 2002.

We will examine the proposal in the light of the institutional arrangements and instruments of French water policy and water resources management. The proposal contains six chapters, three of which are of particular interest:

1. Decentralisation and planning of the management of water resources;

2. services publics for the provision of water and waste water treatment
3. reform of the river basin agencies.

\section{Decentralisation and Planning}

The French system comprises the following six river basins: Artois-Picardie, Rhin-Meuse, Seine-Normandie, Loire-Bretagne, Adour-Garonne, RhoneMéditerrannée-Corse. For each of these river basins, appropriate management organisations have been installed. The principal objectives and strategies of each river basin are contained in the socalled Schéma Directeur de l'Aménagement et de Gestion des Eaux - SDAGE (Principal Guidelines on Water Resources Management). The SDAGE contain descriptions of the overall objectives and the main strategies as well as more detailed documents on actual implementation, including maps. They were adopted for the first time in 1997 after the amendments of the Water Act in 1992. In the future, these SDAGE will keep their original function and also serve as the plans for water resources management which are required by Article 13 of the EU WFD.

At regional and local level, the SDAGE can be complemented by so-called SAGE (Schéma d'Aménagement et de Gestion des Eaux). The new proposal will improve the functioning of such SAGE by a better definition of the rights and obligations of local joint public bodies, such as a group of townships or of local governments, in particular as executive bodies, e.g. as contractors or/ and operators of public works. 
(c) 20I0 Authors; licensee IÖW and oekom verlag. This is an article distributed under the terms of the Creative Commons Attribution Non-Commercial No Derivates License (http://creativecommons.org/licenses/by-nc-nd/3.o/), which permits unrestricted use, distribution, and reproduction in any medium, provided the original work is properly cited. 